\title{
Access to Papanicolaou Test by the Unified Health System users
}

\author{
Acesso ao exame Papanicolau por usuárias do Sistema Único de Saúde
}

Vanessa Franco de Carvalho' ${ }^{1}$, Nalú Pereira da Costa Kerber ${ }^{1}$, Vanessa Andréia Wachholz ${ }^{1}$, Flávia Conceição Pohlmann ${ }^{1}$, Letícia Amico Marques ${ }^{1}$, Fabiane Ferreira Francioni ${ }^{1}$

Objective: to understand how is the access to the public health service users in the Papanicolaou Test. Methods: qualitative study, with 52 women who have changes in the Pap smear exam, questioning the exam achievement frequency and the difficulties of its access and the consultations. It was developed a thematic analysis based on the Fekete accessibility reference. Results: three categories emerged: access to information on the frequency of Pap smears, highlighting the completion of the examination linked only to the professional application; access to Pap smears, in which most women do not have difficulty; access to a return visit, showing the difficulty of women getting back into service after the exam. Conclusion: most women have easy access to the Pap smear. However, there are limitations on the return visit, hindering to establish immediate actions to the beginning of treatment.

Descriptors: Health Services Accessibility; Papanicolaou Test; Secondary Prevention; Nursing.

Objetivo: compreender como se dá o acesso das usuárias do serviço público de saúde ao exame Papanicolau. Métodos: estudo qualitativo, com 52 mulheres que apresentaram alteração no exame Papanicolau, questionando a frequência de realização do exame e as dificuldades de acesso a este e às consultas. Desenvolveu-se análise temática à luz do referencial de acessibilidade de Fekete. Resultados: emergiram três categorias: acesso à informação sobre a frequência do exame Papanicolau, despontando a realização do exame atrelada unicamente à solicitação do profissional; acesso ao exame Papanicolau, em que a maioria das mulheres não possui dificuldade; acesso à consulta de retorno, mostrando a dificuldade das mulheres conseguirem voltar ao serviço após o exame. Conclusão: a maioria das mulheres tem facilidade de acesso para a realização do citopatológico, porém, há limitações quanto à consulta de retorno, dificultando o estabelecimento de ações imediatas para o início do tratamento.

Descritores: Acesso aos Serviços de Saúde; Teste de Papanicolau; Prevenção Secundária; Enfermagem.

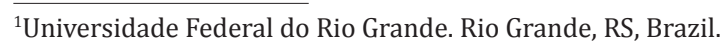




\section{Introduction}

Between 1980 and 2010, the number of cases of cervical cancer in the world increased by $0.6 \%$ per year and the number of deaths caused by it grew by $0.4 \%$ per year, driven by increasing and aging populations, respectively ${ }^{(1)}$.

The discussion of this subject is necessary for view of the fact that this cancer is more common in the North $(23.5 / 100,000)$, the second most frequent in the Midwest $(22.1 / 100,000)$ and northeast $(18.7 / 100,000)$, the fourth in the Southeast $(10.1 / 100,000)$ and the fifth most common in the South $(15.8 / 100,000)$, taking years to develop. For 2014, in Brazil, we have expected 15,590 new cases of cervical cancer, with an estimated risk of 15.3 cases per 100,000 women $^{(2)}$.

Despite its high incidence, this type of cancer is detected early with easy and low-cost measures, such as the Pap smear. In an investigation in northern Paraná, with women who had Pap by the Unified Health System, low test coverage has been checked, and in 2006 , the coverage was $7.6 \%$ among women aged 25-59 years old ${ }^{(3)}$.

Thus, it is notjustonly provide the cytopathology in the basic units; it is necessary to encourage women for their achievement. Despite the strategies used in prevention programs, they especially come up against, in the absence of information, leading to delayed diagnosis and increased mortality ${ }^{(4)}$.

This means that the access must be fully covered, from primary to tertiary care, seeking the satisfaction of needs presented in the health-disease process. Therefore, only the collection of the Pap smear is not enough; it is necessary that the health service enables and be responsible for all women's follow-up in case of changes in the exam.

Screening for cervical cancer involves a complex process such as the performance of Pap smears in identifying positive cases (suspects), confirm the diagnosis and appropriate treatment ${ }^{(5)}$.

Concerning the accessibility, it is essential to think about the relationship between the needs of the population and the provision of health services to meet those needs. Access to services depends not only on the availability of resources but also on the guarantee of its use. Accessibility is ensured by the combination of different dimensions, including, geographical accessibility (distance), organizational accessibility (waiting time for care), socio-cultural accessibility and affordability ${ }^{(6)}$.

Access to the health system still shows a deficit requiring larger investments, as can be seen through research developed the theme. A study in Minas Gerais showed that the difficulty in access to services for the examination had as competing factors such as the belief that the exam is paid; not have access to health facilities to carry out the examination; units performing the examination work during working hours; the unit alleged lack of material for testing; fail to schedule the examination at the health unit ${ }^{(7)}$. Thus, in that instance, it is clearly seen the dimensions of geographic accessibility and affordability affected, compromising access to the system as a whole.

Research conducted in Rio Grande do Sul revealed that among the difficulties encountered in carrying out the Pap smear, there is the misinformation about the exam ${ }^{(8)}$, which conforms to socio-cultural accessibility.

Thinking that the accessibility to the health system is intrinsically related to the first contact with services, since this is the starting point for the prevention of cervical cancer, it is realized the importance of investigating this issue. For this, it is questioned how is women's access to public health services for the performance of the Pap smear, establishing the objective of this study: to understand how the access of the public health service users to take Pap is processed. 


\section{Methods}

Study of qualitative developed with women who had a Pap smear test in January 2010 to July 2011 on the public health service of the city of Rio Grande/ RS.

The inclusion criteria were the result of examination showing any of the following changes: atypical cells of undetermined significance; low-grade intraepithelial lesion; high-grade intraepithelial lesion and; in situ and invasive adenocarcinoma.

In the stipulated period, the network of municipal Health System held 9,681 cytopathology, and 186 showed some of the changes mentioned. Of them, 14 were treated with repeated examinations. Thus, there were 172 results changed. Exclusion criteria were people residence in rural areas, incomplete address to the interview, non-existent address and dangerous locations for access to home visits.

When starting the search for women who fit the inclusion and exclusion criteria, there were some difficulties as provided address belonging to another person, death of the patient; they were not found after conducting home visits at different times. Also, there was the loss of two interviews recorded of technical problems. Thus, 52 women were the study participants.

Data collection was conducted through individual interviews, in the second half of 2011 by four academic nursing and a master's student, who traveled to the home of the subjects after telephone contact. A script guiding the interview was used, containing the following questions: Do you usually carry out preventive examinations of cervical cancer? How often? Where do you usually do your exam? Is it difficult to schedule and take the exam?

After ordering the interviews and organization of data, thematic analysis was conducted with an interpretation based on the Fekete assessment accessibility, seeking a listing of the data presented in the dimensions: geographical accessibility (distance), organizational accessibility (waiting time for care) and socio-cultural accessibility ${ }^{(6)}$.

The sequential numbering of the order of Pap test performance, with the most significant being selected identified the statements that would provide a clear identification of the listed categories.

The study complied with the formal requirements contained in the national and international standards of regulatory research involving human beings.

\section{Results}

Initially, it was sought the location of the cytopathology, highlighting that 37 women did it in the Basic Health Unit next to their residence, 12 women underwent data collection at the University Hospital of the City, two (2) in private consultations and one (1) of the instruments had not that answer.

Having the data from the interviews, it was sought to search of regularity and similarity and then three categories emerged: access to information on the frequency of Pap smear, Pap test access and access to a return visit. Below, there are the listed categories.

\section{Access to information on the frequency of Pap smear}

This category emerged from the assumed relevance of the information to strengthen the access to health services. On frequency in the exam, women proved to be linked to the request of health professionals: I have it every year, when I got injured, they told me to do it every six months (E05). I do not usually do it. Only when they come here, I have to do it, the agents (E06). Always the doctor asks, I do it, I think every two years (E12).

In a similar way, another factor that drew attention in this category was the performance of Pap 
linked to pregnancy. Prenatal consultation appears as a concrete opportunity to prevent women who have not acquired the habit of having regular Pap: Yeah, I did it when I was pregnant and then I did not do it more. I lived there in the interior; there was no hurry; I was waiting, and I do it now, pregnant (E15) ... I did prenatal care with the doctor... and she then said I had to take the exam. So I did it (E49).

\section{Pap test access}

This category was created to guide to the focus of this study that is the access to the cytological collection services. In the analysis of the reports, it can be observed that most women do not have problems with access to services that provide this test, there is no also problems to perform it: No, They do it fast. You get there, schedule it and every Thursday they reap the material (E21). No, no. Every Thursday from 8 o'clock. It is only the schedule, just go to do it. You go in the morning, you go a little earlier, you schedule it, and it is already on the same day (E05).

However, it can be seen in some reports that access to cytopathology service is not always easy. One of the interviewees said even she prefers to take the exam in private health service, by the delay in the public service: To schedule it, we have more difficulty because it has a queue and staff arrive early. So, we have to face the queue (E12). Then sometimes you have to get away, pay, to be faster a little bit (E16).

\section{Access to a return visit}

This category was listed from questioning about the difficulties and scheduling the examination, through the understanding that the universality by the Unified Health System needs to be guaranteed at all levels of care. So, even with few reports of some difficulty, there is a need to explore these lines to devise strategies to minimize the problem.

Among the few difficulties reported, the most cited were the return to health services to meet the test results and for forwarding a new consultation: Ah! I have. There are many difficulties. We have to go at four in the morning there, and there is only five assistance. It has one day, but then after you have the consultation. Your problem is only consulting (E07). Ah! In the health service, we have difficulty, three to four months to one year (E11). The hardest thing is to schedule the same consultation, and I think sometimes it takes a while too. If you are in a hurry, it is more complicated; but if not, it is ok (E12).

Also, it was observed that the difficulty is not only in scheduling the return visit, as two women complained about the delay in the examination analysis and obtaining results: ...The problem is it is late; it is coming from there, coming from there, you know the result if you have something or do not have (E04). To schedule is easy, the problem is to get back the examination (E08).

\section{Discussion}

It can be observed that access to the cytological collection service is facilitated because most women have accessed to this service in basic health unit closest to their place of residence. This is an important finding because it facilitates the access of users, and they do not need large displacements to take care of their health.

This type of offer is by the proposal of Primary Health Care, which proclaims that the first contact made to the nearest unit of residence of users makes the size of the geographical accessibility becomes effective ${ }^{(6)}$.

In the content of the statements that led the categories, it is necessary to highlight the issue of information about the need and importance of performing the Pap test. Access to information about the exam can be taken in two ways. First, it is clear that health professionals are asking and advising women about the examination. Second, women do not have the exam as a routine in their lives, not seeking to do it spontaneously. It was clear, in the speeches that many of them only carry out the cytological exam when there 
is a request of the professional. The same was shown in a study developed in Minas Gerais, where women diagnosed with cervical cancer showed that before discovering this diagnosis, they only performed the screening test when requested by the doctor ${ }^{(7)}$.

This finding is contrary to the study developed in Roraima in 2013, which detected a high prevalence of adherence to examination and $79.5 \%$ of performing reason for this is the periodic routine $\mathrm{e}^{(9)}$.

Therefore, it is still seen the need for investments in public information about the importance of prevention of cervical cancer and the Pap smear. Many women seem to have acquired the culture of preventive care and promoting their health. The dependence of women about a health care professional for the prevention of diseases that emerged in this study may be related to difficulties in socio-cultural accessibility. The socio-cultural accessibility is characterized as a set of phenomena that determine the search for health care, and one of the characteristics of this type of accessibility is the perception that the individual has on his body and disease $^{(6)}$.

The frequency in the cytopathology exam, established by the Ministry of Health in 1988 remains current, touting that this examination is carried out once a year and, every three years after two consecutive negative annual examinations. In the event of any change, the exam frequency can vary ${ }^{(5)}$.

However, it is known that some women have not acquired the habit of performing it at regular intervals as recommended by the Ministry of Health, so health professionals cannot miss any opportunity to mentor women about the importance of routine Pap smear and seize the opportunities that arise to offer the collection of material. A woman should not miss the opportunity to perform screening when she is pregnant ${ }^{(10)}$.

In this sense, the prenatal care is highlighted, as many women attend health services only for these consultations, so it is necessary that in this period, the date of the last cytological examination be investigated, if necessary, and it can be collected at any time of pregnancy ${ }^{(5)}$. In this study, the connection appeared between the collection of this examination and prenatal suggests that prenatal assistants are developing their work properly. However, this finding reinforces the absence of the habit of users to make the Pap test, which shows that among these women there is not yet a culture of care for their health.

However, the importance of the frequency of Pap smears is just in the permanent monitoring of the examination, preventing the cell changes progress to neoplastic processes, to prevent cervical cancer be installed $^{(10)}$.

The Ministry of Health identifies the importance of this issue and has been working for many years for the prevention of cervical cancer. In this sense, Viva Woman was created, the National Program for Control of Cervical Cancer and Mama in 1998. The program has established an integrated network that allowed expanding women's access to health services ${ }^{(11)}$.

The health public service units seem to develop the work of prevention of cervical cancer, increasing women's access to services with an emphasis on health promotion and early detection of problems. Given the results presented, it is also supposed to be no problems with access to cytopathology in Basic Health Units or the Family Health Strategy units that meet most of the women, since they are getting the exam.

One factor contributing to the increased ease of access is the existence of units of the Family Health Strategy because this type of unit works with defined coverage areas, which facilitates community access, as well as the active search when required. The distances to be traveled in search of health services affect the demand for the service, which shows the occurrence of cervical cancer related to the socioeconomic conditions of the population, especially in underdeveloped areas 
with limited access to health services ${ }^{(12)}$.

Another advantage of the Family Health Strategy is constituted by a multi-professional team, and act to facilitate the entry of users into the health service. In the specific case of women, the Family Health Strategy can help in recognizing it as a subject participant in their care ${ }^{(13)}$.

The care model of the Family Health Strategy includes the resources and the organization of the service, for the development of actions to facilitate the achievement of care and access to services. Access has been considered as major health care elements ${ }^{(14)}$.

It is noticed that one of the women alternatives, when there is a difficulty in access to public services, is to look for the particular service, which they consider it more agile and effective. Normally, between such service satisfaction factors, there are access and the rapid flow in care ${ }^{(15)}$.

Similarly, a study conducted in Minas Gerais found that most women do not do the cytopathology exam by the quality of care and work for organization, reporting a preference for flexibility of private services $^{(14)}$.

The same problem was found in another study, conducted in Ceará, where women have not sought a return visit scheduled for public service, for claiming that the fact they have already sought elsewhere ${ }^{(16)}$.

Changes in the organizational system are needed, and primary layout of the collection of cytopathology at different times, to allow access of women workers to health professionals ${ }^{(15)}$.

It is imperative that at the level of primary health care, there is a plan in which the control actions of cervical cancer are scheduled, guaranteed access, keeping records of tests performed and active search for the missing ones, especially those of higher risk ${ }^{(14)}$.

These are issues that deserve a closer look by managers and health professionals, given that there seems to be some weakness in the organization of services. This reflection is based on the difficulties reported by women as the scheduling of the exam, depicting problems in organizational accessibility, such as queues and delays in care. A study in the Northeast found a lack of a job as difficult to carry out the Pap, featuring an institutional barrier to access to the service. Also, they said the fixed schedule for the examination to cause the removal of the search service $^{(17)}$.

This problem of delay in the analysis of the tests and return to consultations schedule for receiving the result shows, once again, difficulties in organizational accessibility. The delay in test results brings great inconvenience to the user, resulting in wasted time, financial loss, by repeated from service in an attempt to find out the result and emotional losses against the uncertainty of the results. This creates distrust in the institution and professionals ${ }^{(14)}$.

Thus, it is clear that not only provide a part of the service, the collection of the Pap test. It is necessary that the woman has information on the result and be assured the necessary monitoring, ensuring the resoluteness of each situation. There are studies showing difficulties in obtaining a definitive diagnosis, monitoring and treatment of intraepithelial and malignant lesions by public services, claiming that adequate coverage screening works with the control of cervical cancer only if the following steps are fulfilled ${ }^{(9)}$.

The speed in this process is determining the quality of care, since in the case of the examination having atypia, the longer the wait for operations, the smaller the chance of favorable prognosis. A large waiting for this type of consultation, which determines the sequence of the attention that should be given to women is unacceptable. It is noteworthy that the participants in this study were women who had changes in Pap smear exam and needed the appropriate follow-up of the case to prevent the 
development of cervical cancer and serious damage to health.

In some services, limitations have been found in the organization of Unified Health System, with limited access and disease control actions, and women with cancer do not get to finish the treatment of cervical cancer, for lack of health organization staff and lack of planning ${ }^{(18)}$.

Among the many objectives of the National Oncological Care Policy, established in 2005, it is highlighted the lines of care organization that encompass all levels of care and the establishment of reference flows and counter-reference to ensure access and comprehensive care to users ${ }^{(19)}$.

Also, the National Oncological Care Policy aimed to improve care by establishing national guidelines for cancer care ${ }^{(19)}$. The orientation of behavior that must be taken before the results of Pap smears is laid in the Brazilian Guidelines for Colon Cancer Tracking, which specifies the procedure to be taken before each change $\mathrm{e}^{(5)}$.

In the investigated city, there is a protocol of care to women's health that specifies the guidelines, supporting the work of professionals and ensuring autonomy for referrals and treatment. This protocol joins the Ministry of Health Behavior manual to guide the continuity of care that should be given to women who have changes in the exam.

Also, the Municipal Health Secretary has a referral service in gynecology, for which the units can refer users, where the resoluteness is not achieved in the basic unit, streamlining consultation, depending on the severity of the cases.

Access to health care should be considered not only as regards the entry, as also the completion of actions to solve the health problems detected.

The issue of access to services still shows up as a weakness of the public health system, not only in the reality investigated. A study in a unit of the Family
Health Strategy, in Mato Grosso, revealed partial accessibility of users, in the sense that the assistance was not always resolute, leading to search for other health units ${ }^{(20)}$.

In this direction, despite showing other data, it also emerges a study conducted in Rio Grande do Sul, involving the cytological results in a Basic Health Unit, which notes a delay of about 50 days for them to be sent to the unit. The authors also found problems in the active pursuit of women due to the inadequacy of the records, making the delivery of results in an effective manner and that would allow adopting the proposed intervention measures quickly ${ }^{(21)}$.

It is believed that the difficulties encountered by the participants of this study in relation to the scheduling of a return visit, can be caused by different organizational factors such as delay in the laboratory in the delivery of examinations, work overload, few health professionals in each unit, difficulty finding the address of active search of women, and great demand of patients with changes in the exam.

It is highlighted the importance of systematic data to enable the necessary information for monitoring of women with changes in cytological and facilitate their tracking.

It is important to remain current addresses and phone numbers in the records, thus making the schedule of consultations for women with abnormal tests faster and easier and thus ensuring continuity in the direction of an efficient and satisfactory service. It reiterates that the delay in returning to the clinic and get the possibility to investigate the case and possible treatment causes women to give up seeking care and put aside the healing opportunity.

All organizational and service bodies have responsibility for ensuring access to users. The Ministry of Health develops policies to improve access to health care, but it is necessary that every municipality is engaged in developing actions to 
encourage women to prevent cervical cancer, for example, through educational activities. Health education is an essential strategy to address issues of prevention of cervical cancer ${ }^{(10)}$.

Finally, it is understood that the nurses and the teams have great relevance and responsibility to plan health actions that promote the strengthening the work process to the need for early diagnosis of cervical cancer and, therefore, allow the ensuring the best care for the female population.

Specifically about professional nurse, it is realized that they have an important role in preventing cervical cancer. Itisusually the professional responsible for calling women to the exam and Pap smear for the collection procedure. Also, it is up to the nurse the management and administration of the health unit, responsible for monitoring cases. Therefore, nursing can assume a role of great importance to the program of prevention of cervical cancer.

\section{Conclusion}

Based on the results, it is possible to have an idea of the real situation in which is the prevention of cervical cancer in the public health system of the municipality investigated.

It was evident that women have easy access to the Pap smear. However, there are limitations on the return visit, hindering the establishment of immediate action for the start of treatment.

Thus, it appears that the public health system presents certain fragility about the comprehensive care and the role of facilitating access to promotion, prevention, care and recovery of women's health since it offers to perform cytological actions and it is not effective in the return consultation.

When using women as subjects of this study who had abnormal test results, the study highlights the problem of access to consultations, as in this case, it is of utmost importance that the return visit is streamlined to avoid the development of the cervix cancer. Health actions need to be implemented quickly, to ensure a full recovery and a healthy lifestyle for women. From the visualized data, strategies can be traced to reduce the present problems and assist women in their entirety.

It is noteworthy an important ally in the streamlining of this service, the proper filing of the information in the records, as it assists in the active search for women who were examined to attend the return visit.

In the organization of the service, diagnostic studies can also be developed, through a tracking system, pointing the reasons for non-adherence of women, identify the availability of community service, to achieve quality control of services, evaluate protocols used and the active search method of patients and ensure proper treatment of women with changes.

\section{Collaborations}

Carvalho VF and Kerber NPC contributed in study design, analysis, article writing, relevant critical review and final approval of the version to be published. Wachholz VA, Pohlmann FC, Marques LA and Francioni FF contributed to the analysis, article writing, relevant critical review, and final approval version to be published.

\section{References}

1. Forouzanfar $\mathrm{MH}$, Foreman KJ, Delossantos AM, Lozano R, Lopez AD, Murray CJL, et al. Breast and cervical cancer in 187 countries between 1980 and 2010: a systematic analysis. Lancet. 2011; 


\section{8(9801):1461-84.}

2. Instituto Nacional de Câncer José Alencar Gomes da Silva. Coordenação de Prevenção e Vigilância Estimativa 2014. Incidência do câncer no Brasil [Internet]. 2014 [citado 2015 maio 25]. Disponível em:http://www.inca.gov.br/estimativa/2014/ estimativa-24042014.pdf

3. Soares MC, Mishima SM, Meincke SMK, Simino GPR. Câncer de colo uterino: caracterização das mulheres em um município do sul do Brasil. Esc Anna Nery. 2010; 14(1):90-6.

4. Gomes CHR, SilvaJA, RibeiroJA, Penna RMM. Câncer cervivo-uterino: correlação entre diagnóstico e realização prévia de exame preventivo em serviço de referência no norte de Minas Gerais. Rev Bras Cancerol. 2012; 58(1):41-5.

5. Instituto Nacional de Câncer José Alencar Gomes da Silva. Coordenação Geral de Ações Estratégicas, Divisão de Apoio à Rede de Atenção Oncológica. Diretrizes brasileiras para o rastreamento do câncer do colo do útero. Rio de Janeiro: INCA; 2011.

6. Fekete MC. Estudo da acessibilidade na avaliação dos serviços de saúde. Brasília: Organização PanAmericana da Saúde; 1997.

7. Silva SR, Silveira CF, Gregório CCM. Motivos alegados para a não realização do exame de Papanicolaou, segundo mulheres em tratamento quimioterápico contra o câncer do colo uterino. Rev Min Enferm. 2012; 16(4):579-87.

8. Casarin MR, Piccoli JCE. Education in health for prevention of uterine cervical cancer in women in Santo Ângelo, state of Rio Grande do Sul, Brazil. Ciênc Saúde Coletiva. 2011; 16(9):3925-32.

9. Navarro C, Fonseca AJ, Sibajev A, Souza CIA, Araújo DS, Teles DAF, et al. Cervical cancer screening coverage in a high-incidence region. Rev Saúde Pública. 2015; 49(17):1-8.

10. Jorge RJB, Sampaio LRL, Diógenes MAR, Mendonça FAC, Sampaio LL. Fatores associados à não realização periódica do exame Papanicolaou. Rev
Rene. 2011; 12(3):606-12.

11. Instituo Nacional do Câncer José Alencar Gomes da Silva. Secretaria de Assistência à Saúde. Viva mulher. Câncer de colo do útero: informações técnico-gerenciais e ações desenvolvidas. Rio de Janeiro: INCA; 2002.

12. Santos RS, Melo ECP. Mortalidade e assistência oncológica no rio de janeiro: câncer de mama e colo uterino. Esc Anna Nery. 2011; 15(2):410-6.

13. Nascimento MSS, Nascimento E, Rossi VEC, Moura JP, Maia MAC, Maciel HPF. Motivos que levaram as mulheres cadastradas no PSF Escola a faltarem ao exame Papanicolau no município de Passos (MG). Ciênc Praxis. 2010; 3(5):17-24.

14. Ribeiro MGM, Santos SMR, Teixeira MTB. Itinerário terapêutico de mulheres com câncer do colo do útero: uma abordagem focada na prevenção. Rev Bras Cancerol. 2011; 57(4):483-91.

15. Sisson MC, Oliveira MC, Conill EM, Pires D, Boing AF, Fertonani HP. Satisfação dos usuários na utilização de serviços públicos e privados de saúde em itinerários terapêuticos no sul do Brasil. Interface Comun Saúde Educ. 2011; 15 (36):12336.

16. Gomes LM, Bezerra AKP, Moreira CTV, Falcão Junior JSP. Exame de papanicolau: fatores que influenciam as mulheres a não receberem 0 resultado. Enferm Global. 2010; 9(3):1-11.

17. Diógenes MAR, Jorge RJB, Sampaio LRL, Mendonça FAC, Sampaio LL. Barreiras a realização periódica do papanicolaou: estudo com mulheres de uma cidade do nordeste do Brasil. Rev APS. 2011;14(1):12-8.

18. Silva MMP, Lagana MTC, Simpson CA, Cabral AMF. Acess to health services for the control of cancer of the uterine cervix in primary care. J Res Fundam Care Online [Internet]. 2013 [citado 2015 mai 25]; 5(3):273-82. Disponível em: http://www. seer.unirio.br/index.php/cuidadofundamental/ 
article/view/2042/pdf_867

19. Ministério da Saúde (BR). Portaria n 2.439/GM, de 8 de dezembro de 2005. Institui a Política Nacional de Atenção Oncológica: promoção, prevenção, diagnóstico, reabilitação e cuidados paliativos, a ser implementada em todas as unidades federadas, respeitadas as competências das três esferas de gestão. Brasília: Ministério da
Saúde; 2005.

20. Corrêa ACP, Ferreira F, Cruz GSP, Pedrosa ICF. Acesso a serviços de saúde: olhar de usuários de uma unidade de saúde da família. Rev Gaúcha Enferm. 2011; 32(3):451-7.

21. Risso, BBS, Soares, MC. Avaliação dos registros do exame citopatológico em uma unidade básica de saúde em Rio Grande-RS. Rev Enferm Saúde. 2011; 1(1):84-90. 